\title{
Alveolar Hypoxia Increases Small Pulmonary Wedge Pressure in Awake Young Lambs
}

\author{
IHOMAS A. HAZIXSKI ANI) KATHILEN A. KINVHIY

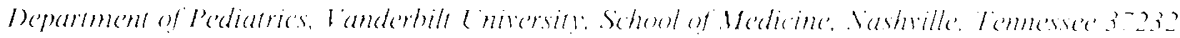

\begin{abstract}
ABSIRACI. Alveolar hypoxia increases pulmonary artery pressure in lambs and sheep but increases lung lymph flow only in lambs; the reasons for this are unknown. To test the hypothesis that hypoxia-induced pulmonary venous constriction could in part explain the fluid filtration response in young lambs, eight young lambs $(13 \pm 3$ days old ) and four older lambs $(60 \pm 4$ days old) were prepared for chronic studies of pulmonary hemodynamics, gas exchange, and fluid filtration. In all animals, a 5 Fr eatheter was intermittently wedged into a distal pulmonary artery to indirectly estimate pulmonary venous pressure. The pressure measured in this manner was termed the "small wedge pressure." Animals were awake, spontaneously breathing, and unsedated, and were exposed to both acute and chronic isocarbic hypoxia $\left(\mathrm{KIO} \mathrm{O}_{2} 0.12\right.$ ). We found that hypoxia significantly increased both small pulmonary wedge pressure and lung lymph flow in young lambs but that neither of these effects occurred in the older lambs. In young lambs, the hypoxia-induced increase in small wedge pressure could be lowered by sodium nitroprusside administration, and small wedge pressure could be increased by angiotensin II infusion. We conclude that alveolar hypoxia increases pulmonary venous tone and the critical pressure of pulmonary veins in young lambs, and that these effects disappear with maturation. These data suggest that alterations in pulmonary venous tone can have important effects on lung fluid balance in the newborn. (Pediatr Res 22: 679-682, 1987)
\end{abstract}

\section{Abbreviations}

TPVR, total pulmonary vascular resistance DSPVR, distal segment pulmonary vascular resistance PVR, pulmonary vascular resistance

\footnotetext{
Hypoxia increases pulmonary ascular resistance yet the sites and mediators of this effect are still uncertain (1. 2). Howerer. the sites of hypoxia-induced vasoconstriction should strongly influence lung thuid balance, since transwascular pressure gradients may also be aftected (3). This is illustrated by the contrast ing effects of hy poxia on the pulmonary circulation of lambs and sheep. In awake lambs, alveolar hypoxia increases cardiac output. pulmonary artery pressure. and lung lymph flow: left atrial pressure does not change and the protein concentration of lymph

Recoived March 17. 1987: accepted July 30. 1987

(orrespondence lhomas A. Hazmski. Mi.1). Deparment of Pediatrics. Vanderbilt I niversity School of Medicine. Nashville, IX37?32?

Supported in part by a grant from the American I ung Association $1.7 \mathrm{~s}-\mathrm{V} 1 \mathrm{l}$ and hy Newborn I.ung SCOR III.14214.K.K. Was supported by a training grant

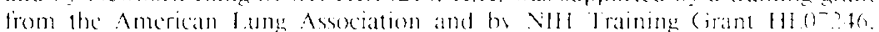
T.A.11, is the recipient of a career Investigator Award from the American Inang Association.
}

relative to plasmat falls (4): the fluid filtation response also oceurs in anesthetized mechanically ventilated lambs whose cardiate output does not increase during hypoxia (5.6). In shecp. howerer. an equivalent degree of hypoxia causes similar incrases in pulmonary artery pressure and cardiac output. but lymph flow and its protein concentration do not change (7. 8). These datia suggest that hypoxia inceases microvascular pressure in hypoxic lambs but not in hypoxic shecp. but the ratsons are untinown. In lambs. possible mechanisms could be cither monunilorm arterial vasoconstriction, pulmonary venous constriction. (1) a combination of both. Recently. Hansen a al. (9) showed that in anesthetized young lambs, hypoxia increased lymph flow and changed the distribution of lung perfusion and that these changes occurred in normoxic lambs given angiotensin II. They proposed that nonuniform arterial vasoconstriction accounted for the increase in lung lymph flow. However, it is equally possible that and redistribution of hlood flow was the result of uniform vemous constriction with a subseguent uniform increase in microsasculat" filtration pressure (10). 11). The purpose of this study was of examine this latter possibility: i.e. that constriction of pulmonary veins was, at least in part. responsible for the lymph flow response to hypoxia in lambs. To test this hypothesis, young and ofder lambs were prepared for chronic studies of pulmonary hemodynamics, gas exchange, and lung fluid filtration: pulmonary venous pressure was measured indirectly. He interpert our results to indicate that pulmonary venous pressure incrased in hypoxic young lambs. that this venous pressure drove lymph flow. and that these changes did not oceur in the older an imals.

\section{MATHRINIS ANI) MIIHH()ISS}

Fight young lambs (age $6 \pm+$ dass) and four older lambs (age $49 \pm 2$ days) were surgically prepared using previously described methods (5.6). After local ancsthesia was administered. catheters were inserted inte the inferier vena calla and descending atorta through hindlimh vessels. Aler general anesthesia was indered with $50 \%$ nitrous oxide and $1-2 \%$ halothane, a keft thoracentemy was performed, and catheters were inserted into the pulmonary artery and left atrium. and a thermister wire 3 PR. American lidwards I abs. Irvine. ( A) was placed in the pulmonary artery for subsequent measurement of cardiac output. After a i-das recovery period a right thoracotomy was performed and a catheter was placed in the efferent duct of the caudal mediastimal lymph node in four boung and thece older lambs: the node was transected and sysemic lymphatics were identified and divided. A catheter was placed in the pleural spate for meatsurement of pleural pressure. Finally in all animals the right jugular woin was punctured percutaneously and a rubber-sealed vascular sheath

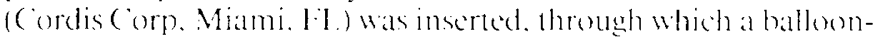
tipped. double lumen pulmonary wedge catheter $5 \mathrm{FR}$. outer diameter $1.67 \mathrm{~mm}$ ) was positioned in the distal pulmomary arkery. This catheter could be intermitently advaneed and medged with the balloon uninflated) to measure pulmomary venous pressure in pulmonary veins of a siec cepual to the wedged 
catheter $(12,13)$. This pressure was termed "small wedge pressure" (13). Animals recovered from surgery for at least $72 \mathrm{~h}$ before studies began. The young lambs were $13 \pm 3$ days old and the four older lambs were $60 \pm 4$ days old when they were studied.

Mean vascular and pleural pressures were measured at endexpiration using saline-filled catheters and standard pressure transducers; these pressures were recorded continuously on a Hewlett-Packard 8-channel recorder. Vascular pressures were referenced to mean pleural pressure; pleural pressure was referenced to a location on the chest identified at surgery to be at the level of the left atrium. Before pleural pressure measurement, the catheter was flushed with $0.1 \mathrm{ml}$ bubble-free saline. The outflow height of the lymph catheter was initially placed at the level of the olecranon, and all lymph catheters were the same diameter and length. The outflow height of the lymph catheter was adjusted if inferior vena cava pressure changed, as recently suggested (14). Lymphatic resistance and catheter resistance were not calculated.

Lymph and plasma protein concentrations were estimated by a calibrated refractometer and confirmed by an automated biuret method (15). Arterial blood gas tensions and $\mathrm{pH}$ were analyzed using standard electrodes and the values were corrected for body temperature. Cardiac output (measured as pulmonary blood flow) was obtained using the thermodilution technique (Cardiac Index Computer SP1435, Gould-Statham, Oxnard, CA); three injections of cold saline were performed over a 30 -s period and the mean was calculated.

Calculations of TPVR were computed using the formula: TPVR = (pulmonary artery pressure - left atrial pressure)/ pulmonary blood flow. DSPVR was computed using the formula DSPVR $=($ small pulmonary wedge pressure - left atrial pressure)/pulmonary blood flow.

Statistics. For comparison of means between normoxic and hypoxic lambs, the paired $t$ test was used. To compare young lambs with older lambs, the unpaired $t$ test was used. When a mean was compared more than once, Bonferoni's correction was used (16). All data in tables and text are presented as the mean $\pm 1 \mathrm{SD}$.

\section{STUDY PROTOCOLS}

Acute isocarbic hypoxia. While the animals breathed air, baseline measurements of pleural pressure and the vascular pressure in the inferior vena cava, left atrium, aorta, pulmonary artery, and pulmonary wedge position were recorded for at least $1 \mathrm{~h}$. In two young lambs and two older lambs, the position of the wedged catheter was identified fluoroscopically. In these animals, the wedge catheter tip was less than $2 \mathrm{~cm}$ above or below the left atrial catheter tip, indicating, along with other physiologic evidence that the catheter was measuring hydrostatic pressure under zone 3 conditions (see "Discussion"). The same pressure was recorded each time regardless of catheter tip position.

Determinations of cardiac output were performed every 15 min for $1 \mathrm{~h}$. Then the breathing mixture was changed to $12 \%$ oxygen in nitrogen; this gas was delivered into a large clear plastic bag which was placed over the animal's head. To keep arterial $\mathrm{pH}$ constant during hypoxia, flow into the bag and the leak around the animal's neck were adjusted to maintain the arterial $\mathrm{PO}_{2}$ near 40 torr and the arterial $\mathrm{PCO}_{2}$ similar to that measured when the animals breathed air. Each animal breathed this gas for $10 \mathrm{~min}$, and all variables were recorded again. We chose to expose lambs to $10 \mathrm{~min}$ of hypoxia, although previous studies $(5,7)$ showed that the hemodynamic response to acute hypoxia was near steady-state after $6 \mathrm{~min}$. Then the lamb resumed room air breathing and all variables were measured until they returned to baseline levels.

Prolonged isocarbic hypoxia. In four young lambs and three older lambs, measurements of lung fluid filtration and hemodynamics were made for a 1.5 - to 3 -h baseline period, and during
$1.5-4 \mathrm{~h}$ of isocarbic hypoxia. These studies of prolonged hypoxia were done on the day after the acute studies.

\section{RESULTS}

Acute hypoxia. In every young lamb, acute isocarbic hypoxia significantly increased pulmonary artery and wedge pressures and increased the pressure difference between the pulmonary wedge position and the left atrium (Table 1). A typical experiment depicting two episodes of hypoxia is shown in Figure 1. Total PVR increased from $5.4 \pm 1.2$ to $8.1 \pm 2.3$ torr $/$ liter $/ \mathrm{min}$ $(p<0.01)$, and distal segment PVR increased from $0.54 \pm 0.21$ to $2.05 \pm 0.44$ torr/liter/min $(p<0.01)$.

In every older lamb, acute isocarbic hypoxia increased only pulmonary artery pressure and cardiac output, and only total PVR significantly increased from $3.9 \pm 0.4$ to $5.4 \pm 0.7$ torr/ liter/min $(p<0.02)$. Distal segment PVR fell slightly but the difference was not significant.

Ventilation and gas exchange data are shown in Table 2. In hypoxic young lambs, only arterial $\mathrm{PO}_{2}$ and respiratory frequency changed significantly $(p<0.03)$. In hypoxic older lambs, only arterial $\mathrm{PO}_{2}$ was significantly different.

Table 1. Pulmonary vascular pressures and cardiac output in study animals in air and after 10 min of isocarbic hypoxia (mean $\pm 1 S D$ )

\begin{tabular}{|c|c|c|c|c|}
\hline & \multicolumn{3}{|c|}{ Vascular pressure (torr) } & \multirow[b]{2}{*}{$\begin{array}{l}\text { Cardiac output } \\
\text { (liter/min) }\end{array}$} \\
\hline & $\begin{array}{c}\text { Pulmonary } \\
\text { artery }\end{array}$ & $\begin{array}{c}\text { Small } \\
\text { pulmonary } \\
\text { wedge }\end{array}$ & $\begin{array}{c}\text { Left } \\
\text { atrium }\end{array}$ & \\
\hline \multicolumn{5}{|c|}{$\begin{array}{l}\text { Young lambs ( } n \\
\quad=8)\end{array}$} \\
\hline Air & $18 \pm 4$ & $3 \pm 2$ & $2 \pm 2$ & $2.83 \pm 0.40$ \\
\hline $12 \% \mathrm{O}_{2}$ & $32 \pm 3^{*}$ & $8 \pm 2^{*}$ & $1 \pm 2$ & $3.40 \pm 0.71^{*}$ \\
\hline \multicolumn{5}{|c|}{$\begin{array}{l}\text { Older lambs ( } \\
\quad=4)\end{array}$} \\
\hline $\begin{array}{l}\text { Air } \\
12 \% \mathrm{O}_{2}\end{array}$ & $\begin{array}{l}15 \pm 3 \\
25 \pm 4^{*}\end{array}$ & $\begin{array}{l}4 \pm 2 \\
4 \pm 2\end{array}$ & $\begin{array}{l}2 \pm 3 \\
2 \pm 3\end{array}$ & $\begin{array}{l}3.26 \pm 0.43 \\
4.23 \pm 0.50^{*}\end{array}$ \\
\hline
\end{tabular}

* Significant difference, $p<0.05$.
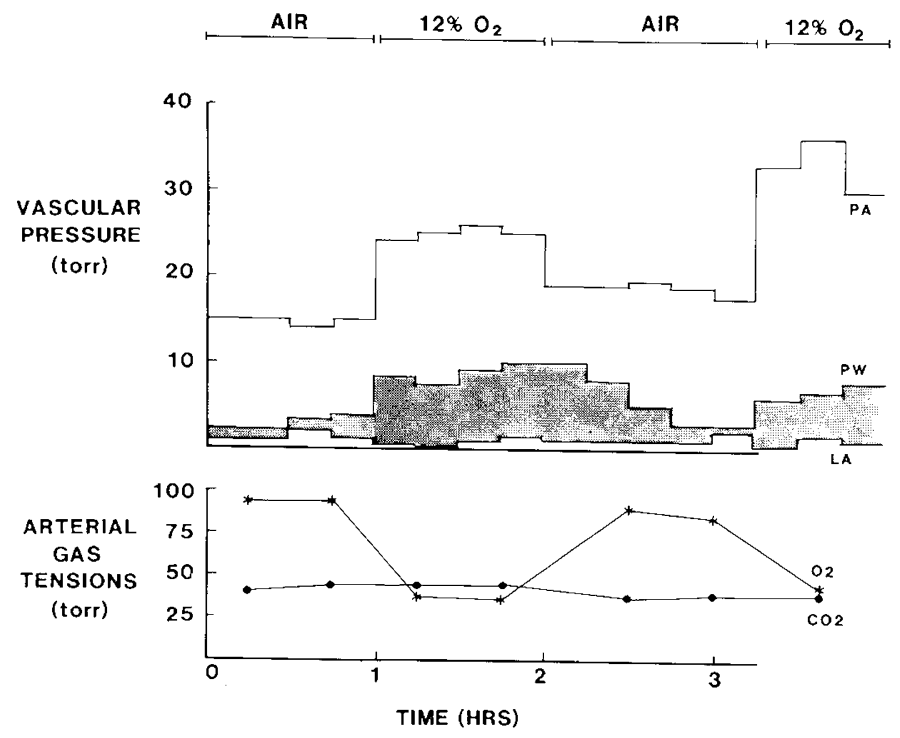

Fig. 1. Pulmonary vascular pressure and arterial gas tensions recorded during two consecutive episodes of alveolar hypoxia in a 12-day-old lamb. The gradient between pulmonary wedge $(P W)$ pressure and left atrial $(L A)$ pressure shown as the shaded area. 


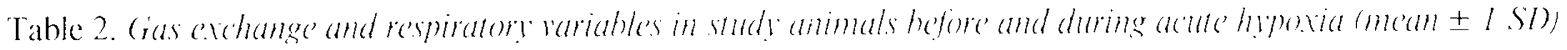

\begin{tabular}{|c|c|c|c|c|c|}
\hline & $\mathrm{pH}$ & $\begin{array}{l}\mathrm{PC}\left(\mathrm{O}_{2}\right. \\
(\mathrm{torr})\end{array}$ & $\begin{array}{l}\mathrm{PO}= \\
(\mathrm{torr})\end{array}$ & $\begin{array}{l}\text { Respiratory frequency } \\
\text { (breaths/min) }\end{array}$ & $\begin{array}{l}\text { Pleural pressure } \\
\text { (torr) }\end{array}$ \\
\hline \multicolumn{6}{|c|}{ Young lambs $(n=8)$} \\
\hline Air & $7.42 \pm 0.07$ & $42 \pm 3$ & $89 \pm 6$ & $60 \pm 11$ & $-2 \pm 1$ \\
\hline $12 \%(\mathrm{O}$ & $7.44 \pm 0.10$ & $40 \pm 4$ & $39 \pm 3^{*}$ & $78 \pm 21^{*}$ & $-3 \pm 1$ \\
\hline \multicolumn{6}{|c|}{ Older lambs $(n=4)$} \\
\hline$\wedge \mathrm{ir}$ & $7.40 \pm 0.04$ & 4()$\pm 2$ & $91 \pm 5$ & $55 \pm 16$ & $-3 \pm 1$ \\
\hline $12 \%()_{2}$ & $7.42 \pm 0.08$ & $41 \pm 3$ & 4()$\pm 4^{*}$ & $61 \pm 17$ & $-4 \pm 2$ \\
\hline
\end{tabular}

Table 3. Fuid filtration variables in sud! animals (monean \pm I SD)

\begin{tabular}{|c|c|c|c|c|c|}
\hline $\begin{array}{c}\text { Pulmonary } \\
\text { artery } \\
\text { (torr) }\end{array}$ & $\begin{array}{c}\text { Small } \\
\text { pulmonary } \\
\text { wedge } \\
\text { (torr) }\end{array}$ & $\begin{array}{l}\text { I.eft atrium } \\
\text { (torr) }\end{array}$ & $\begin{array}{l}\text { Cardiac output } \\
\text { (liter } / \mathrm{min})\end{array}$ & $\begin{array}{c}\text { I. }{ }^{(\mathrm{m} m p h} \text { flow } \\
(\mathrm{ml}) \mathrm{h})\end{array}$ & 1./P ratio* \\
\hline $17 \pm 2$ & $4 \pm 1$ & $3 \pm 1$ & $2.88 \pm 0.03$ & $3.5 \pm 0.4$ & $0.65 \pm 0.2$ \\
\hline $31 \pm 3+$ & $11 \pm 2+$ & $3 \pm 1$ & $3.52 \pm 0.11 \%$ & $6.9 \pm 0.5 t$ & $0.52 \pm 0.24$ \\
\hline $15=$ & $5 \pm 1$ & $4 \pm 1$ & $3.05 \pm 0.41$ & $4.1 \pm 0.4$ & $0.6 .3 \pm 0.2$ \\
\hline $24 \pm 3+$ & $5 \pm 2$ & $4 \pm 1$ & $3.67 \pm 0.34 \%$ & $4.2 \pm 0.8$ & $(0.61 \pm 0 . .3$ \\
\hline
\end{tabular}

* I.ymph to plasma protein concentration ratio.

+ Indicates $p<0.05$ compared to bascline period in air.

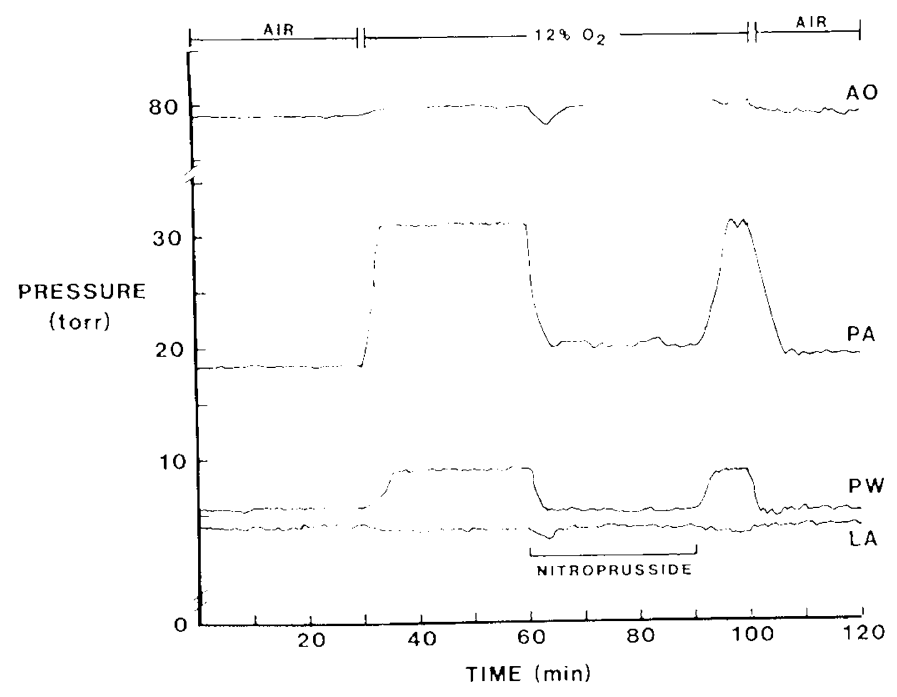

Fig. 2. Fffect of sodium nitroprusside infusion on vascular pressures during hypoxia in a 14-day-old lamb. This nonspecific vasodilator reduced the vascular pressure in the pulmonary artery $(P \cdot 1)$. pulmonary wedge position (l'I), and left atrium $(/ .1)$ with no change in aortic pressure $(A O)$. This response was consistent in three young lambs.

IFid fillration during prolonged hypovia. Fluid filtration variables in four young lambs and three older lambs are shown in Table 3. Because the vascular pressure in the inferior vena cava increased by less than 1 torr during hypoxia, only small adjustments in lymph catheter height were necessary. In young lambs. as expected (4-6). prolonged hypoxia increased lymph flow and decreased the protein concentration of lymph relative to plasma. In the hypoxic older lambs, as expected $(7,8)$, neither lymph flow nor lymph protein concentration changed. In all study animals, the plasma protein concentration remained unchanged so that the fall in this ratio always reflected the fall in lymph protein concentration.
Idditional studies. To determine whether the increase in small pulmonary wedge pressure and in distal segment PVR could be accounted for by contraction of vascular smooth muscle. sodium nitroprusside (ESI Pharmaceuticals. Cherry Hill. V.I) a nonspecific vasodiator. was administered by continuous infusion to three hypoxic young lambs. The drug was given by continuous infusion at a dose of $1 \mathrm{mg} / \mathrm{kg} / \mathrm{min}$. An example of the response to nitroprusside infusion is shown in Figure 2. Nitroprusside decreased both pulmonary artery and pulmonary wedge pressure with little change in either left atrial pressure or in cardiac output. This response was consistent in all three lambs.

Finally, in three normoxic roung lambs (two of whom had lymph cannulas). we administered the pulmonary vasoconstrictor angiotensin II (Angiotensin, (iba. Summit, VJ). $11-15 \mu \mathrm{g} /$ $\mathrm{kg} / \mathrm{min}$. for $90 \mathrm{~min}$ after a 2 -h baseline period. Angiotensin II infusion was adjusted to maintain pulmonary artery pressute at twice the baseline level: when this occurred. small pulmonary wedge pressure increased from $3 \pm 1$ to $10 \pm 2$ torr. I eft atrial pressure and arterial blood gases did not change and cardiac output fell by $4 \pm 2(r$. In two young animals with lymph catheters. lymph flow increased 48 and $60 \%$ after 45 min of infusion. and the average lymph-10-plasma protein concentration ratio fell from 0.62 to 0.50 . This demonstrates that angiotensin II infused at a rate sufficient to double pulmonary artery pressure without increasing pulmonary blood flow can also increase pulmonary wedge pressure and lymph flow.

\section{DISc (ission}

We found that. in roung lambs, alveolar hypoxia increased small pulmonary wedge pressure. shifted the arterial-to-venous distribution of vascular resistance loward the left atrium, and increased lung lymph fow. Vone of these changes occurred in hypoxic older lambs.

Several lines of eridence suggest that this hypoxia-induced increase in small pulmonary wedge pressure represents pulmonary venous constriction in the young lambs. First. a catheter wedged into a small pulmonary artery (under $/$ one 3 conditions) has been shown to accurately measure the pressure in pulmonary 
veins of similar size (13). In our lambs, the catheter was wedged satisfactorily as indicated by 1) the similarity of its phasic pressure waveform to the left atrial pressure waveform at all times; 2 ) the fact that when all animals breathed air the small pulmonary wedge pressure was always 1-2 torr higher than left atrial pressure; and 3) the inability to obtain mixed venous blood from the wedged catheter, indicating that the catheter was not in series with an adjacent small pulmonary artery. We did not directly cannulate pulmonary veins in this study, since an additional thoracotomy would have been required.

The conventional measurement of pulmonary wedge pressure by using balloon inflation technique ("large wedge pressure") can be influenced by the vertical height of the wedged catheter tip relative to the heart (17), and this same effect might possibly influence the measurement of small wedge pressure as well. However, we believe that our measurements were made under zone 3 conditions as evidenced by the following: 1) when the catheter was pulled back $1-1.5 \mathrm{~cm}$ from the wedged position and the balloon inflated, we always measured a "large wedge pressure" that was within 1 torr of the directly measured left atrial pressure $(13,18) ; 2)$ the fluoroscopic results indicated that the wedged catheter was nearly level with the left atrium; 3) the fact that in small supine animals most of the lung is in zone 3 condition (18); and 4) the fact that all reported pressures were measured at end-expiration when alveolar pressure equaled zero, so that left atrial pressure was at least 4 torr higher than alveolar pressure.

Our results in young, awake hypoxia lambs are similar to those of Mitzner and Sylvester (19) who found in isolated perfused pig lungs that hypoxia increased fluid filtration into the lung by an amount that was independent of blood flow. They interpreted these data to indicate that hypoxia increased microvascular filtration pressure by increasing the critical pressure of a vascular segment either in capillaries or in pulmonary veins. The idea of a critical pressure was first presented to account for the failure of Poiseuille's law to adequately predict flow through vessels which had both elastic properties and active tone. This idea was extended by others $(11,20)$ who suggested that in the pulmonary circulation, alveolar pressure was a critical pressure in that it, not outflow pressure, (i.e. left atrial pressure) could determine the actual pressure gradient for flow. Recently, Jasper et al. (21) have extended this idea by showing that even under zone 3 conditions (i.e. where outflow pressure is greater than alveolar pressure), a spectrum of critical pressures may be present. Our data in hypoxic young lambs are consistent with this line of reasoning, and suggest that in young lambs, alveolar hypoxia increases pulmonary venous tone, which increases the average critical pressure in these vessels, and thus increases microvascular filtration pressure.

A second line of evidence that pulmonary venous constriction is occurring in the young lambs is the small wedge pressure response to nitroprusside and angiotensin II infusions. Pulmonary venous pressure can be passively increased if bronchial blood flow increases (22) or if severe edema compresses pulmonary veins (23). However, these mechanisms are unlikely, since in our study two vasoactive agents immediately altered small wedge pressure. These responses indicate that smooth muscle constriction within the walls of pulmonary veins was responsible for the increase in wedge pressure during hypoxia.

Other investigators using different methods and species have also found that pulmonary venous pressure increases during hypoxia (24-28). Recently, investigators using the micropuncture method have reported that venous pressure increases during hypoxia in isolated young lamb and adult cat lungs $(29,30)$. Fung and coworkers $(31,32)$ have shown that pulmonary veins are uniquely anatomically suited to control microvascular pressure, since they are tethered by elastic elements and thus cannot easily collapse but can actively constrict. The present study suggests that the hypoxia-induced increase in pulmonary venous tone explains why lymph flow increases in hypoxic lambs but not in hypoxic sheep. These data suggest further that alterations in venous tone can have important effects on lung fluid balance in the newborn lung, but that this vasoactivity may change with maturation.

\section{REFERENCES}

1. Fishman AP 1976 Hypoxia on the pulmonary circulation: how and where it acts. Circ Res 38:221-231

2. Voelkel NF 1986 Mechanisms of hypoxic pulmonary vasoconstriction. Am Rev Respir Dis 133:1186-1195

3. Taylor AE 1981 Capillary fluid filtration: Starling forces and lymph flow. Circ Res 49:558-575

4. Bressack MA, Bland RD 1980 Alveolar hypoxia increases effects of alveolar hypoxia on lung fluid and protein transport in unanesthetized sheep. Cir Res 40:269-274

5. Hansen TN, Haberkern CM, Hazinski TA, Bland RD 1984 Lung fluid balance in hypoxic lambs. Pediatr Res 18:434-440

6. Hansen TN, Hazinski TA, Bland RD 1984 Effects of asphyxia on lung fluid balance in baby lambs. J Clin Invest 74:370-376

7. Bland RD, Demling RH, Selinger SL, Staub NC 1977 Lung fluid filtration in unanesthetized newborn lambs. Circ Res 46:111-116

8. Coates G, O'Brodovich H, Jefferies AL, Gray GW 1984 Effects of exercise on lung lymph flow in sheep and goats during normoxia and hypoxia. J Clin Invest 74:133-141

9. Hansen TN, LeBlanc AL, Gest AL 1985 Hypoxia and angiotensin II infusion redistribute lung blood flow in lambs. J Appl Physiol 8:812-818

10. Hutlgren HN High altitude pulmonary edema. In: Staub NC (ed) Lung, Water and Solute Exchange. Marcel Dekker, Inc., New York, pp 437-469

11. Lopez-Muniz R, Stephens NL, Bromberger-Barnea B, Permutt S, Riley RL 1968 Critical closure of pulmonary vessels analyzed in terms of starling resistor model. J Appl Physiol 24:625-635

12. Malik AB, Kidd BSL 1976 Pulmonary arterial wedge and left atrial pressures and the site of hypoxic pulmonary vasoconstriction. Respiration 33:123132

13. Zidulka A, Hakim TS 1985 Wedge pressure in large vs small pulmonary arteries to detect pulmonary venoconstriction. J Appl Physiol 59:1329-1332

14. Drake R, Geisler M, Laine G, Gabel J, Hansen T 1985 Effect of outflow pressure on lung lymph flow in unanesthetized sheep. J Appl Physiol 58:7076

15. Gornall AG, Bardawill GJ, David MM 1949 Determination of serum proteins by means of the biuret reaction. J Biol Chem 177:751-769

16. Zar JH 1974 Biostatistical Analysis. Englewood Cliffs, NJ, Prentice-Hall, Inc 17. Todd TRJ, Baile EM, Hogg JC 1978 Pulmonary arterial wedge pressure in
hemorthagic shock. Am Rev Respir Dis 118:613-616

18. West JB, Dollery CT, Naimark A 1964 Distribution of blood flow in isolated lung; relation to vascular and alveolar pressures. J Appl Physiol 19:713-724

19. Mitzner W, Sylvester JT 1981 Hypoxic vasoconstriction and fluid filtration in pig lungs. J Appl Physiol 51:1065-1071

20. Permutt S, Riley RL 1963 Hemodynamics of collapsible vessels with tone: the vascular waterfall. J Appl Physiol 18:924-932

21. Jasper AC, Spencer LS, Goldberg HS 1986 Relationship of arterial wedge pressure to closing pressure in the pulmonary circulation. Am Rev Respir pressure to closing $143: 879-884$

22. Warren RL, Powell WJ 1986 Acute alveolar hypoxia increases bronchopulmonary shunt flow in the dog. J Clin Invest 77:1515-1524

23. Charan NB, Turk GM, Dhand R 1984 Gross and subgross anatomy of bronchial circulation in sheep. J Appl Physiol 57:658-664

24. Furnival CM, Linden RJ, Snow HM 1970 The effect of hypoxia on the pulmonary veins. J Physiol 210:43-44

25. Morgan BC, Church SC, Guntheroth WG 1968 Hypoxic constriction of pulmonary artery and vein in intact dogs. $J$ Appl Physiol 25:356-361

26. Hyman AL, Kadowitz PJ 1975 Effects of alveolar and perfusion hypoxia and hypercapnia on pulmonary vascular resistance in the anesthetized intubated 2 month old lamb. Am J Physiol 228:397-403

27. Kuida $\mathrm{H}$, Tasagaris TJ, Hecht HH 1963 Evidence for pulmonary venoconstriction in brisket disease. Circ Res 12:182-189

28. Rivera-Estrada C, Saltzmon PW, Singer D, Katz LN 1958 Action of hypoxia on the pulmonary vasculature. Circ Res 6:10-14

29. Nagasaka Y, Bhattacharya J, Nanjo S, Gropper MA, Staub NC 1984 Micropuncture measurement of lung microvascular pressure profile during hypoxia in cats. Circ Res 54:90-95

30. Raj JU, Rorhback J, Chen P 1986 Micropuncture measurement of lung microvascular pressures during hypoxia in newborn lambs. Clin Res 34:154A

31. Fung YC, Sobin SS, Tremer H, Yen MRT, Ho HH 1983 Patency and compliance of pulmonary veins when airway pressure exceeds blood pressure. J Appl Physiol 54:1538-1539

32. Fung YC 1984 Biodynamics: Circu' Springer-Verlag, New York, pp 213219 